\title{
Expression of Cyp21a1 and Cyp11b1 in the fetal mouse testis
}

\author{
Liangbiao Hu, Ana Monteiro, Heather Johnston, Peter King ${ }^{1}$ and Peter J O'Shaughnessy \\ Division of Cell Sciences, University of Glasgow Veterinary School, Institute of Comparative Medicine, Bearsden \\ Road, Glasgow G61 1QH, UK and ${ }^{1}$ William Harvey Research Institute, Molecular Endocrinology Centre, Bart's and \\ The London, Queen Mary, University of London, London EC1M 6BQ, UK
}

Correspondence should be addressed to PJ O'Shaughnessy; Email: p.j.oshaughnessy@vet.gla.ac.uk

\begin{abstract}
Fetal Leydig cells and fetal adrenocortical cells may share a common progenitor cell. Both cell types show several similarities, particularly in relation to their primary steroidogenic function. Differences in steroid secretion are largely due to the expression of 21-hydroxylase (CYP21A1) and 11ß-hydroxylase (CYP11B1) activity in the adrenal. To determine whether expression of these enzymes defines a clear difference between adrenocortical and Leydig cells, or is further evidence of a link between the cell types, we have measured Cyp21a1 and Cyp11b1 expression and related enzyme activity in the fetal testis. Expression of both Cyp21a1 and Cyp11b1 was clearly detectable in the fetal testis by RT-PCR and Southern blotting. Real-time PCR studies showed that Cyp11b1 was expressed only in the fetal/neonatal testis with no expression in the pubertal or post-pubertal animal. Cyp21a1 was also predominantly expressed in the fetal testis although some lower expression was also seen in the adult. Expression of Cyp21a1 and Cyp11b1 in neonatal testicular cells was unaffected by incubation in vitro with human chorionic gonadotrophin or ACTH. Using immunohistochemistry, CYP21A1 was localised to a subset of interstitial steroidogenic cells in the fetal testis although CYP11B1 was not detectable. Incubation studies showed that 21-hydroxylase activity was present in the tissue although $11 \beta$-hydroxylase activity could not be detected. Results indicate that a subpopulation of steroidogenic cells in the fetal testis express Cyp21a1 and show 21-hydroxylase activity. This may provide further evidence of a link between fetal Leydig cells and adrenocortical cells but does not discount the possibility that these steroidogenic cells represent 'ectopic' adrenal cells.
\end{abstract}

Reproduction (2007) 134 585-591

\section{Introduction}

During normal testis development in the mouse, two generations of Leydig cells arise sequentially. A fetal population appears shortly after testis differentiation and is responsible for masculinisation of the fetus while an adult population arises around day 7 after birth and is required for normal adult androgen production (Vergouwen et al. 1991, Baker et al. 1999, Nef \& Parada 1999). The fetal Leydig cells differentiate from mesenchymal-like stem cells around $12.5 \mathrm{dpc}$ in the mouse (Byskov 1986), although the origin of these stem cells remains uncertain with both the coelomic epithelium (Karl \& Capel 1998) and mesonephros (Merchant-Larios \& Moreno-Mendoza 1998, Val et al. 2006) as possible sources.

In support of a mesonephric origin of fetal Leydig stem cells, it has been suggested that fetal Leydig cells and adrenocortical cells share a common origin based on expression patterns of $S f-1$ in the developing gonadal ridge (Hatano et al. 1996). The adrenal gland develops adjacent to the gonad at the same time and these authors suggest that both cell types share a common precursor cell which arises around $10.5 \mathrm{dpc}$ at the cranial end of the mesonephros. This hypothesis is supported by the similarities that exist between fetal adrenal and fetal Leydig cells. Both are regulated by pituitary hormones and are primarily steroidogenic cells sharing a common steroidogenic pathway from cholesterol to progesterone. The major steroid secreted by the cells depends on the presence of $17 \alpha$-hydroxylase (CYP17A1) and $17 \beta$ hydroxysteroid dehydrogenase (HSD17b3) in the testis and 21-hydroxylase (CYP21A1) and 11 $\beta$-hydroxylase (CYP11B1) in the adrenocortex although CYP17A1 has been shown to be expressed in the fetal adrenal (Heikkila et al. 2002). In further support of the concept that fetal adrenal and fetal Leydig cells may share a common precursor, we have shown recently that fetal Leydig cells express the melanocortin type 2 receptor $(\mathrm{MC} 2 \mathrm{R})$ and that they are sensitive to adrenocorticotrophic hormone (ACTH), the principal trophic stimulator of the adrenal cortex (Johnston et al. 2007). In addition, adrenocortical cells will express the luteinising hormone (LH) receptor and will respond to $\mathrm{LH}$ following hyperstimulation (Kero et al. 2000). One of the major differences between the two cell types, therefore, is the expression of CYP21A1 and CYP11B1 in the adrenal cortex which allows secretion of corticosteroids. In order to determine whether expression of these enzymes defines a clear 
difference between adrenocortical and Leydig cells, we set out to establish whether Cyp21a1 and Cyp11b1, and associated enzyme activity, are expressed in the fetal testis and to characterise that expression.

\section{Results}

\section{Testicular mRNA expression during development}

To determine whether Cyp11b1 and Cyp21a1 are expressed in the testis, cDNA prepared from fetal and adult testis was amplified by PCR and the presence of amplified product determined by Southern hybridisation. Results in Fig. 1 show that the full-length coding region of Cyp11b1 was expressed in the fetal testis but not in the adult testis (Fig. 1A) while Cyp21a1 was expressed in both fetal and adult testis (Fig. 1B). As expected, there was also clear expression of both Cyp11b1 and Cyp21a1 in the adrenal. While both fetal and adult testis expressed full-length Cyp21a1, a shorter transcript was also apparent in both. Sequencing of PCR products identified two alternate transcripts (Fig. 1C). Transcript $C$ is the correct size for the major alternate transcript seen in Fig. 1B. Transcript B was not clearly seen on the Southern blots and is likely, therefore, to be a minor product.

The general steroidogenic pathways found in the adrenal and testis are shown in Fig. 2A. Real-time PCR was used to measure developmental changes in the expression levels of Cyp11b1 and Cyp21a1 in the testis (Fig. 2B) and, for comparison, expression of mRNA encoding the testicular steroidogenic enzymes HSD3B6, CYP11A1 and CYP17A1 was also measured. Data from the real-time studies show that Cyp11b1 is only expressed in the fetal and neonatal testis and that expression is lost after day 10 (Fig. 2B). HSD3B6 is only expressed in the adult Leydig cell population (Baker et al. 1999) and expression of Hsd3b6 is first seen as expression of Cyp11b1 is lost. Expression of Cyp21a1 was similar to Cyp11b1 except that a low level of mRNA persisted into adulthood (Fig. 2B). Both Cyp11b1 and Cyp21a1 showed peak levels of mRNA at E18 which coincided with the fetal expression peak of the Leydig cell genes Cyp11a1 and Cyp17a1.

Incubation of neonatal testicular cells in vitro with human chorionic gonadotrophin (hCG) or ACTH had no effect on expression of Cyp21a1 or Cyp11b1 (Fig. 3). In the same experiment, testosterone production by the cells was stimulated by both hormones (basal, $0.4 \pm$ 0.1 pmol; hCG, $18.1 \pm 2.1$ and ACTH, 20.4 \pm 3.3 ).

\section{Enzyme immunolocalisation}

Immunohistochemistry was used to try to identify cell types expressing Cyp11b1 and Cyp21a1 in the neonatal testis. Expression of CYP21A1 was restricted to the interstitial tissue and to cells that also express CYP11A1,

\section{A Cyp11b1}

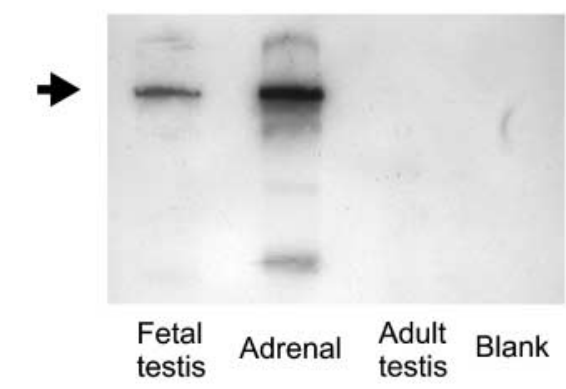

\section{B Cyp21a1}
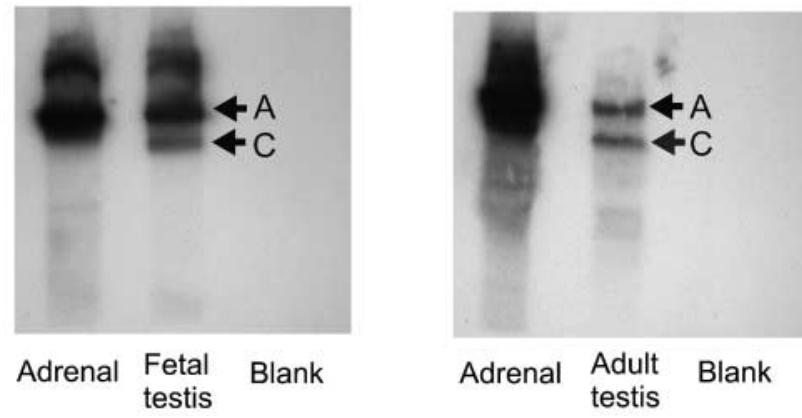

\section{Gene structure of Cyp21a1}

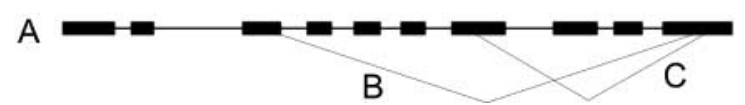

Figure 1 Expression of Cyp11b1 and Cyp21a 1 in the fetal and adult testis. Total RNA from each tissue was reverse transcribed, amplified by PCR and visualised by Southern blot hybridisation. (A) Expression of Cyp 11 b1 in fetal testis, adult testis and adrenal. The position of the expected full-length transcript (1704 bp) is shown with an arrow. (B) Results from two experiments showing expression of Cyp21a1 in fetal testis, adult testis and adrenal. The position of the expected full-length transcript (1464 bp) is shown with an arrow labelled A. An alternate transcript is shown with an arrow labelled $\mathrm{C}$ which corresponds to structure $\mathrm{C}$ shown in part C. (C) Structure of alternate transcripts of Cyp21a1 identified in fetal testis. Solid boxes represent exons while lines represent introns. (A) represents the fulllength transcript while (B) and (C) show the structure of two different alternate transcripts.

a specific Leydig cell marker in the testis (Ikeda et al. 1994; Fig. 4). All cells that expressed CYP21A1 also expressed CYP11A1, although there were a number of cells expressing CYP11A1 which did not express CYP21A1 (Fig. 4). Expression of CYP11B1 was not detectable in the testis by immunohistochemistry.

\section{Enzyme activity}

To determine whether mouse testes show 21-hydroxylase and $11 \beta$-hydroxylase activity, testicular homogenates were incubated with enzyme substrate and products isolated by thin-layer chromatography (TLC). Figure 5 

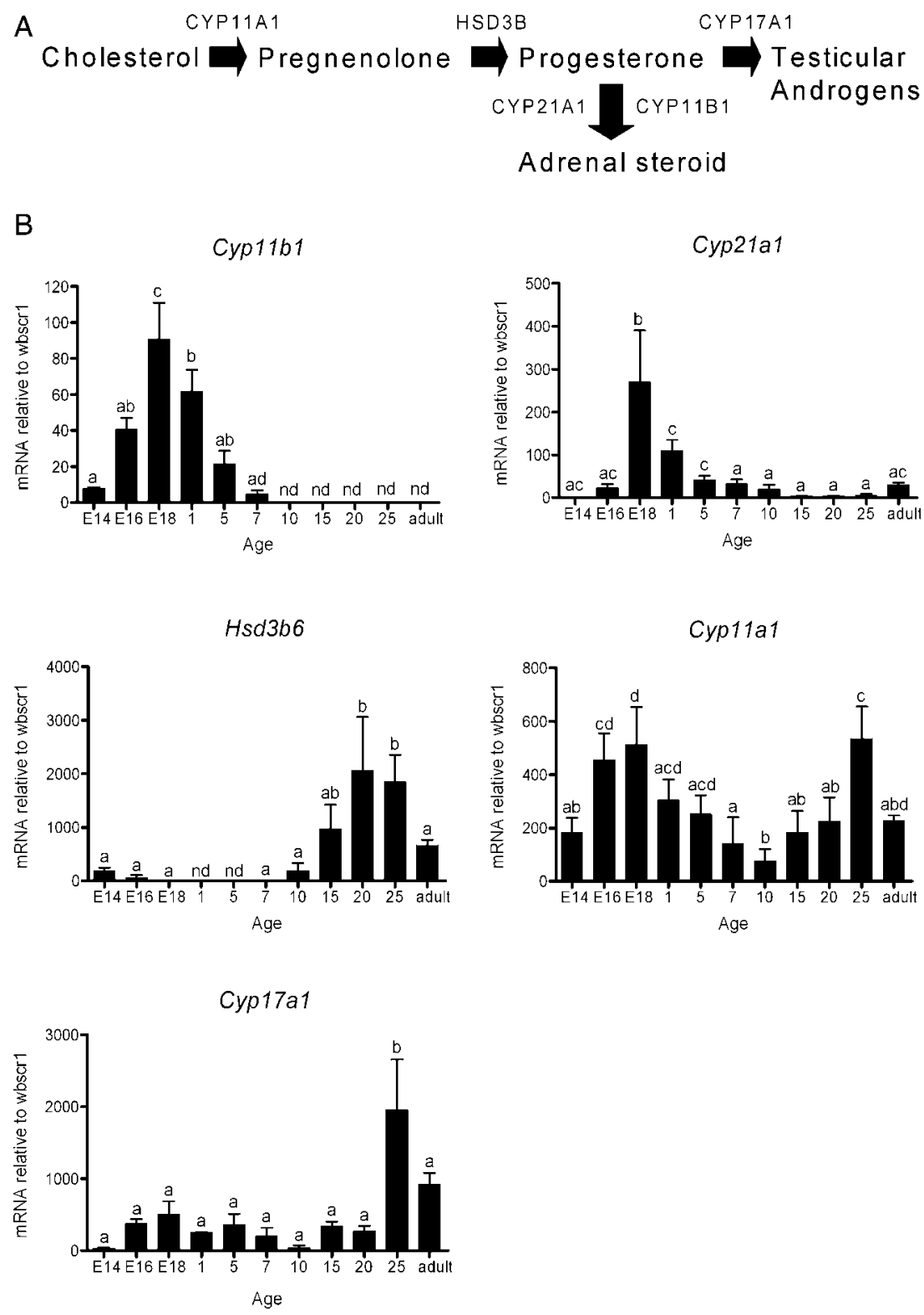

Figure 2 (A) Steroidogenic pathways in the testis and adrenal. The enzymes which catalyse each step in the pathway are shown. HSD3B, 3ßhydroxysteroid dehydrogenase (types 1 and 6); CYP11A1, cytochrome P450 side chain cleavage; CYP17A1, cytochrome P450 17 $\alpha$-hydroxylase; CYP11B1, cytochrome P450 11ß-hydroxylase and CYP21A1, cytochrome P450 21-hydroxylase. (B) Expression levels of Cyp11b1, Cyp21a1, Hsd3b6, Cyp11a1 and Cyp17a1 mRNA in the mouse testis during development. Enzyme expression was measured by real-time PCR and bars represent the mean \pm S.E.M. of data from four animals. Groups with at least one shared letter superscript are not significantly different. nd, not detectable.

shows a time-course of $\left[{ }^{3} \mathrm{H}\right]$ progesterone metabolism by homogenate of neonatal testis. As expected, most of the substrate was metabolised to $17 \alpha$-hydroxyprogesterone and androgen (androstenedione plus testosterone). There was also, however, low but clear metabolism to deoxycorticosterone and 11-deoxycortisol which would both be formed by 21-hydroxylase activity. Confirmation of the identity of the 21-hydroxylated products was obtained through HPLC analysis following initial TLC separation. There was no clear further metabolism of these products to corticosterone or cortisol in this or similar experiments. To determine whether the neonatal testis expresses $11 \beta$ hydroxylase activity homogenate was incubated with $\left[{ }^{3} \mathrm{H}\right]$ deoxycorticosterone. Under these conditions, we were unable to detect activity associated with $\left[{ }^{3} \mathrm{H}\right]$ corticosterone following TLC and HPLC separation of products.

\section{Discussion}

The Leydig and adrenocortical cells share many similarities, not least of which are the primary steroidogenic function of the cells and their responsiveness to 
A

Cyp21a1

B

Cyp11b1

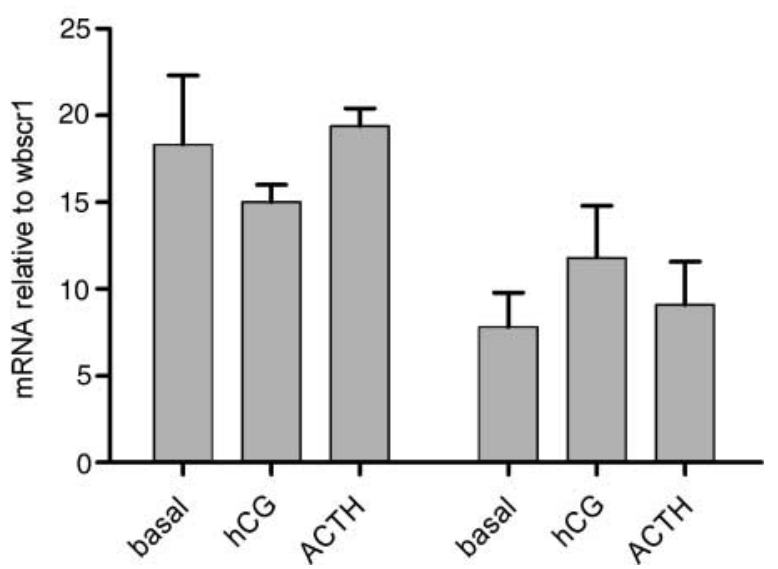

Figure 3 Expression of Cyp21a1 and Cyp11b1 in neonatal testicular cell stimulated by ACTH or hCG. Cells isolated from mouse neonatal testes were incubated under basal conditions or in the presence of $\mathrm{ACTH}$ $\left(10^{-7} \mathrm{M}\right)$ or hCG $\left(10^{-9} \mathrm{M}\right)$ for $3 \mathrm{~h}$. Expression of specific mRNA species was measured by real-time PCR as described in Material and Methods.

pituitary hormones. The nature of the steroid hormones generated by each cell type depends on the steroidogenic enzymes expressed and the predominant production of androgen by the Leydig cells depends largely upon expression of Cyp17a1. Expression of Cyp21a1 and Cyp11b1 in the fetal mouse testis means that both the fetal testis and adrenal express all genes which code for essential components of the corticosteroid synthetic pathway. Taking into account other similarities between the cell type (e.g. expression of $\mathrm{Mc} 2 \mathrm{r}$ in the fetal Leydig cells (O'Shaughnessy et al. 2003), expression of Cyp17 in the fetal adrenal (Heikkila et al. 2002) and LH receptor expression in the adrenal (Kero et al. 2000)) results described here would tend to support the hypothesis that both cell types originate from a common precursor (Hatano et al. 1996). It is also clear, however, from the immunohistochemical data that CYP21A1 is only expressed in a subpopulation of steroidogenic cells. A recent study by Val et al. (2006) has also shown by in situ hybridisation that Cyp11b1 is only expressed in a subpopulation of steroidogenic cells in the fetal testis. Cells which express the 'adrenal' enzymes may, therefore, be a subpopulation of fetal Leydig cells or may represent ectopic adrenal cells which have migrated from the adrenal during early differentiation (Heikkila et al. 2002, Jeays-Ward et al. 2003). Migration of cells from the adrenal to the gonad is normally inhibited by WNT4, however, and in the normal animal, the number of cells following this path is likely to be very few (Heikkila et al. 2002) and unlikely to explain the levels of gene expression and enzyme activity seen in this study. A definitive demonstration of a common origin of fetal Leydig cells and fetal adrenal cells is likely to require labelling and detailed tracking of the putative precursors.

CYP21A1 converts progesterone to deoxycorticosterone and is the essential first step in glucocorticoid synthesis. Our studies show that the enzyme is expressed in the fetal testis with expression declining markedly after birth. During development, two populations of Leydig cells arise sequentially. The fetal Leydig cells arise soon after testis differentiation in the mouse and are subsequently replaced, at least functionally, by the adult population which starts to develop in the post-natal, pre-pubertal period (Baker et al. 1999, Nef \& Parada 1999). The pattern of expression of Cyp21a1 determined by real-time PCR would be consistent, therefore, with expression in the fetal Leydig cells. Residual expression of Cyp21a1 in the adult may be due to the persistence of fetal Leydig cells in the adult or to low expression in the adult cell population. It has been shown previously that CYP21A1 is not detectable by Western blotting in the adult testis which is consistent with the low levels of expression seen by real-time PCR $(\mathrm{Hu}$ et al. 2002). Interestingly, however, in Cyp11a1-null mice, there is detectable expression of CYP21A1 in the interstitial tissue probably due to increased levels of $\mathrm{ACTH}$ or $\mathrm{LH}$ in these mice (Hu et al. 2002). It has previously been reported that extra-adrenal 21-hydroxylase activity in the human and adult rat is not mediated through Cyp21a1 (Mellon \& Miller 1989). It is clear, however, from the PCR/Southern blots and from sequencing of PCR products that Cyp21a1 is expressed in the fetal mouse testis. Failure to detect Cyp21a1 in the adult rat testis is consistent with this enzyme being predominantly associated with the fetal testis, while lack of expression in the fetal human testis may indicate a species difference (Mellon \& Miller 1989).

The final step in glucocorticoid biosynthesis is $11 \beta$-hydroxylation of deoxycorticosteroids by CYP11B1. It has previously been reported that the fetal testis expresses Cyp11b1 (Hatano et al. 1996, Val
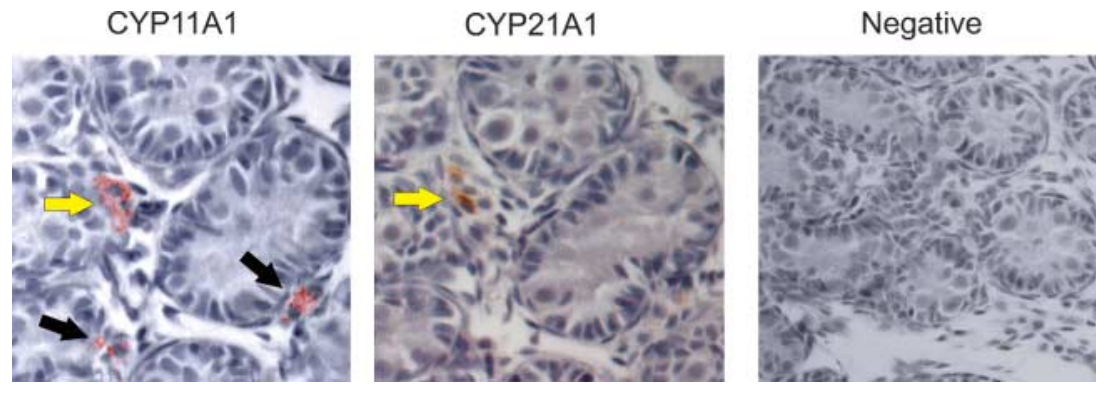

Figure 4 Immunohistochemical localisation of CYP11A1 and CYP21A1 in the neonatal testis. Adjacent sections of testes $(5 \mu \mathrm{m})$ from a neonatal mouse were incubated with antibody to CYP11A1 or CYP21A1 and visualised following binding to a biotinylated secondary antibody. Cells expressing both CYP11A1 and CYP21A1 are indicated with a yellow arrow while cells expressing CYP11A1 alone are indicated with black arrows. The negative section had no primary antibody added. 


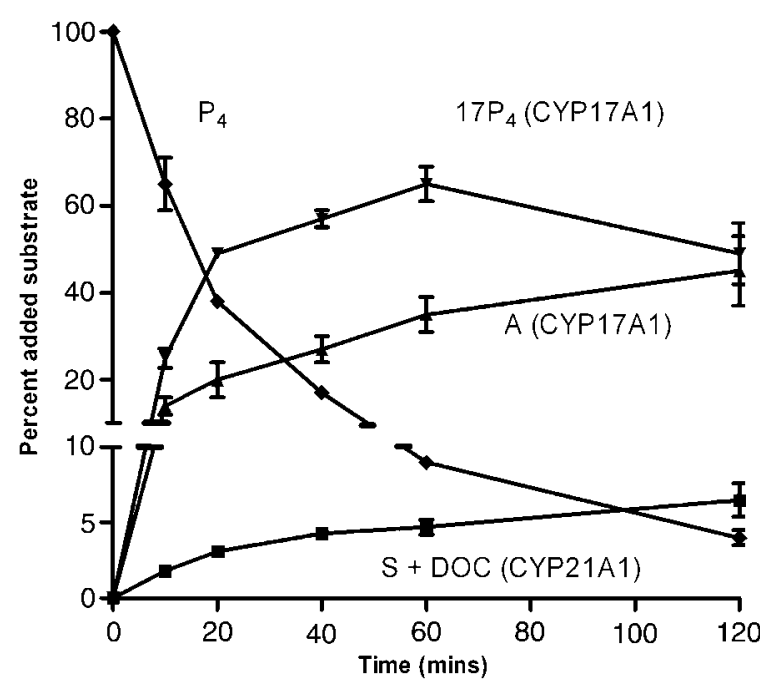

Figure 5 Steroidogenic enzyme activity in the neonatal testis. The figure shows the time-course of progesterone metabolism by testicular homogenate. Neonatal testicular homogenates were incubated with $\left[{ }^{3} \mathrm{H}\right]$ progesterone for different times and products were separated by TLC. Results show steroids formed as a percent of the added substrate. To simplify the graph the products of 21-hydroxylase activity (11deoxycortisol and deoxycorticosterone) are combined (labelled S+ DOC) while the androgens, androstenedione and testosterone are also combined (labelled A). Beside each relevant steroid, the protein likely to be responsible for the illustrated conversion is shown in parentheses.

et al. 2006) and the results reported here confirm that full-length transcripts are expressed in the fetal mouse testis. Failure to detect CYP11B1 protein or $11 \beta$ hydroxylase activity in the fetal testis suggests, however, that suppression of translation may occur. Regulation of translation through, for example, microRNA is an established developmental mechanism (Good 2003) which would, in this case, act to prevent significant corticosterone production by the testis. This is consistent with the very low levels of corticosteroids detected in medium from fetal testes incubated in vitro (O'Shaughnessy et al. 2003). Corticosteroids act to inhibit Leydig cell function and in the adult rat $11 \beta$ hydroxysteroid dehydrogenase (11 $\beta \mathrm{HSD})$ oxidises corticosteroids and thereby limits their effect (Hardy et al. 2005). Fetal and neonatal animals lack $11 \beta \mathrm{HSD}$ (Phillips et al. 1989) and inhibition of Cyp11b1 translation may, therefore, be a protective mechanism that prevents high levels of corticosteroid production by the testis. This hypothesis would suggest that CYP21A1 may not play a significant role in normal Leydig cell function and that expression of Cyp21a1 may be a remnant of Leydig cell evolution (O'Shaughnessy et al. 2006).

Expression of Cyp21a1 and Cyp11b1 in the fetal testis is further evidence of a link between the developing testis and adrenal. It is likely that this expression is in a subpopulation of fetal Leydig cells and this subpopulation may form during Leydig cell differentiation from pluripotent stem cells that arise from the coelomic epithelium (Yao et al. 2002, Cui et al. 2004) or may arise separately from the mesonephros towards the end of initial testis differentiation (Val et al. 2006). Thus, in the fetal testis, most or all fetal Leydig cells express MC2R and respond to ACTH (Johnston et al. 2007) while a subpopulation of cells also expresses genes encoding 'adrenal' steroidogenic enzymes.

\section{Materials and Methods \\ Animals}

The mice used in this study were bred at the University of Glasgow Veterinary School and were maintained as required under United Kingdom Home Office regulations. Normal mice, bred on a C3H/Heh-101/H genetic background, were derived from stock animals originally obtained from the MRC Radiobiology Unit (now the MRC, Mammalian Genetics Unit, Harwell, UK). To time fetal development, males and females were caged overnight and the morning was designated as fetal day 0.5 of pregnancy. The day of birth was designated as post-natal day 1 .

\section{Cell isolation and incubation}

Dispersed testicular cells from neonatal mice were prepared by collagenase treatment of whole testes as previously described (Stalvey \& Payne 1983). Testes from six animals were dispersed at $37^{\circ} \mathrm{C}$ in DMEM/F12 containing $1 \mathrm{mg} / \mathrm{ml}$ collagenase (Worthington CLS type 4, purchased from Lorne Laboratories Ltd, Twyford, UK), and isolated cells were filtered through a nylon sieve with a pore size of $50 \mu \mathrm{m}$. Aliquots of isolated cells $(1 \mathrm{ml}$ total) were incubated for $3 \mathrm{~h}$ at $37^{\circ} \mathrm{C}$ in DMEM/F12 in an atmosphere of $5 \% \mathrm{CO}_{2}$ and in the presence or absence of hCG $\left(10^{-7} \mathrm{M}\right)$ or ACTH $(1-24)$ $\left(10^{-9} \mathrm{M}\right.$; Sigma-Aldrich Co). At the end of the incubation period, cells and medium were separated by centrifugation at $150 \mathrm{~g}$ and the cell pellet stored in liquid $\mathrm{N}_{2}$.

\section{RT-PCR and Southern blotting}

Total RNA was extracted using Trizol (Life Technologies). Isolated RNA was reverse transcribed using random hexamers and Moloney murine leukaemia virus reverse transcriptase (Superscript II, Invitrogen) as described previously (O'Shaughnessy \& Murphy 1993, O'Shaughnessy et al. 1994). This cDNA was used as a template for subsequent PCRs. The PCRs were carried out in a total volume of $50 \mu \mathrm{l}$ using a 'hot-start' Taq polymerase (1.25 units AmpliTaq Gold, Applied Biosystems, Warrington, Cheshire, UK) in buffer (15 mM Tris- $\mathrm{HCl}(\mathrm{pH} 8.0), 50 \mathrm{mM} \mathrm{KCl}$ and $2.5 \mathrm{mM} \mathrm{MgCl}_{2}$ ) containing dNTPs (0.2 $\mathrm{mM}$ each), primers (200 nM each) and template. Reactions were started by $10 \mathrm{~min}$ at $95^{\circ} \mathrm{C}$ followed by up to 35 cycles of $95^{\circ} \mathrm{C}$ for $30 \mathrm{~s}, 60{ }^{\circ} \mathrm{C}$ for $30 \mathrm{~s}$ and $72{ }^{\circ} \mathrm{C}$ for 2 min.

The primers used to amplify the full-length coding region of Cyp21a1 and Cyp11b1 were: Cyp21a1, forward: ATGCTGCTACCTGGGCTGCTG and reverse: TCAAGGACGCTCACCCTGGTCT; Cyp11b1, forward: GATGACAATGGCTCTCAGGGTGAC and reverse: GAGAGGGCAATGTGTCATCAGA. 
An internal probe for Southern hybridisation of Cyp21a1 was amplified by PCR from adrenal CDNA using primers TGCTGTTGCTGCTGCTAGCTGG and CAACGTGCTGTCCTTGTCTCCAAA while a probe for Cyp11b1 was amplified using TCAGGGTGACAACATATGTGTGGCT and CCATTCTGGCCCATTTAGCAA. These primers generate amplicons of 511 and 411 bp respectively. The products of these reactions were gel-purified, sequenced and used for Southern hybridisation as described below.

\section{Real-time PCR}

Levels of specific mRNA species were measured by real-time PCR using the SYBR Green method following RT of the isolated RNA. Real-time PCRs were performed in a 96-well plate format using a Stratagene MX3000 cycler. Reactions contained $5 \mu \mathrm{l} 2 \times$ SYBR MasterMix (Stratagene, Amsterdam), primer $(100 \mathrm{nM})$ and template in a total volume of $10 \mu \mathrm{l}$. The thermal profile used for amplification was $95^{\circ} \mathrm{C}$ for $8 \mathrm{~min}$ followed by 40 cycles of $95^{\circ} \mathrm{C}$ for $20 \mathrm{~s}, 63{ }^{\circ} \mathrm{C}$ for $20 \mathrm{~s}$ and $72{ }^{\circ} \mathrm{C}$ for $30 \mathrm{~s}$. At the end of the amplification phase, a melting curve analysis was carried out on the products formed and gel electrophoresis was carried out on representative samples to confirm product size.

Primers for real-time PCR were designed using parameters previously described (Czechowski et al. 2004) and the amplicons all crossed at least one exon/exon boundary. The primers used were:

\section{Cyp21a1 forward CAAGAAACTCTCTCGCTCAGСССТ reverse CAACGTGCTGTCCTTGTCTCCAAA $\begin{array}{lll}\text { Cyp11b1 forward } & \text { TGCCCTTGGAATCCTGGATAGT } \\ \text { reverse } & \text { CCATTCTGGCCCATTTAGCAA }\end{array}$ \\ Cyp11a1 forward CACAGACGCATCAAGCAGCAAAA reverse GCATTGATGAACCGCTGGGC \\ HSD3b6 forward GCTCCAGAGTGGGAGTGCTGACAC reverse AATCCTCTGGCCCAAAAACССТC \\ Cyp17a1 forward TGGCCCСATCTATTCTCTTCGCCTG reverse AGGCGACGCCTTTTCCTTGG.}

\section{Sequencing}

PCR products were sequenced directly or were ligated into plasmid using TOPO TA cloning kits (Invitrogen) and sequence obtained from the cloned plasmid. Sequencing reactions were carried out using big dye terminator cycle sequencing kits (Applied Biosystems).

\section{Southern hybridisation}

For Southern hybridisation of PCR products, the DNA was transferred from agarose gels to nitrocellulose membranes and hybridised with a $\left[{ }^{32} \mathrm{P}\right]$ labelled cDNA probe prepared as above (O'Shaughnessy et al. 1994).

\section{Enzyme activity}

Steroidogenic enzyme activity was measured in homogenates of fetal testis and adrenal using tritiated substrate as described previously (O'Shaughnessy et al. 2000). Tissues were homogenised in PBS and incubated with $\left[1,2,6,7-{ }^{3} \mathrm{H}\right]$ progesterone (Amersham) or $\left[1,2,6,7-{ }^{3} \mathrm{H}\right] 21$-hydroxyprogesterone at $37{ }^{\circ} \mathrm{C}$ in the presence of $1 \mathrm{mMNADPH}$. The $\left[{ }^{3} \mathrm{H}\right] 21$-hydroxyprogesterone substrate was generated from $\left[{ }^{3} \mathrm{H}\right]$ progesterone by incubation with adult mouse adrenal homogenate. At the end of the incubation period, $50 \mu \mathrm{g}$ non-radioactive carrier steroids were added to each sample along with $\left[{ }^{14} \mathrm{C}\right]$ testosterone and $\left[{ }^{14} \mathrm{C}\right]$ androstenedione (2000 d.p.m./sample) to measure recovery. Samples were extracted twice with $5 \mathrm{ml}$ toluene and steroids were separated by TLC using polyester-backed silica gel plates (Whatman Ltd, Maidstone, UK). A two-step TLC separation was used; initially, plates were developed in chloroform/methanol (97/3) which separated cortisol, corticosterone, deoxycorticosterone, 11-deoxycortisol, testosterone and 17-hydroxyprogesterone. Progesterone and androstenedione were not separated in this system and they were eluted from the first TLC plate and separated by subsequent TLC in chloroform/ether (7/1). The identity of products was confirmed by reverse-phase HPLC using a C18 $4 \mu \mathrm{m}$ column as described previously (Mannan \& O'Shaughnessy 1988).

\section{Immunohistochemistry}

Neonatal testes were fixed in 4\% paraformaldehyde for $1 \mathrm{~h}$ and then washed in $70 \%$ ethanol, dehydrated and embedded in paraffin. Sections $(5 \mu \mathrm{m})$ were mounted on glass slides, dewaxed and rehydrated. Endogenous biotin was blocked using an avidin/biotin blocking kit (R\&D systems Europe Ltd, Abingden, UK) and sections were incubated with primary antibody overnight at $4{ }^{\circ} \mathrm{C}$. The antibodies used were rabbit anti-human CYP21A1 (LAE Biotech International, Rockville, MD, USA), mouse anti-rat CYP11B1 monoclonal (Chemicon International, Temecula, CA, USA) and rabbit anti-bovine P450scc (gift from A $\mathrm{H}$ Payne). Sections were washed and incubated for $30 \mathrm{~min}$ with biotinylated secondary antibody (R\&D systems Europe Ltd). Bound antibody was visualised using 3,3-diaminobenzidine tetrahydrochloride (R\&D systems Europe Ltd). Negative controls without the primary antibody were included in each experiment.

\section{Statistical analysis}

Data were analysed by ANOVA followed by Fisher's multiple comparison test.

\section{Acknowledgements}

This work was supported by a grant from the BBSRC (grant number BBS/B/01359). We would like to thank Dr A H Payne for provision of antibody to Cyp11a1. The authors declare that there is no conflict of interest that would prejudice the impartiality of this scientific work. 


\section{References}

Baker PJ, Sha JA, McBride MW, Peng L, Payne AH \& O'Shaughnessy PJ 1999 Expression of 3ß-hydroxysteriod dehydrogenase type I and VI isoforms in the mouse testis during development. European Journal of Biochemistry 260 911-916.

Byskov A 1986 Differentiation of mammalian embryonic gonad. Physiological Reviews 66 77-112.

Cui S, Ross A, Stallings N, Parker KL, Capel B \& Quaggin SE 2004 Disrupted gonadogenesis and male-to-female sex reversal in Pod1 knockout mice. Development 131 4095-4105.

Czechowski T, Bari RP, Stitt M, Scheible WR \& Udvardi MK 2004 Real-time RT-PCR profiling of over 1400 Arabidopsis transcription factors: unprecedented sensitivity reveals novel root- and shoot-specific genes. Plant Journal 38 366-379.

Good L 2003 Translation repression by antisense sequences. Cellular and Molecular Life Sciences 60 854-861.

Hardy MP, Gao HB, Dong Q, Ge R, Wang Q, Chai WR, Feng X \& Sottas C 2005 Stress hormone and male reproductive function. Cell Tissue Research 322 147-153.

Hatano O, Takakusu A, Nomura M \& Morohashi K 1996 Identical origin of adrenal cortex and gonad revealed by expression profiles of Ad4BP/SF-1. Genes Cells 1 663-671.

Heikkila M, Peltoketo H, Leppaluoto J, Ilves $M$, Vuolteenaho $O$ \& Vainio $S$ 2002 Wnt-4 deficiency alters mouse adrenal cortex function, reducing aldosterone production. Endocrinology 143 4358-4365.

Hu MC, Hsu NC, El Hadj NB, Pai Cl, Chu HP, Wang CK \& Chung BC 2002 Steroid deficiency syndromes in mice with targeted disruption of CYP11A1. Molecular Endocinology 16 1943-1950.

Ikeda Y, Shen WH, Ingraham HA \& Parker KL 1994 Developmental expression of mouse steroidogenic factor-1, an essential regulator of the steroid hydroxylases. Molecular Endocinology 8 654-662.

Jeays-Ward K, Hoyle C, Brennan J, Dandonneau M, Alldus G, Capel B \& Swain A 2003 Endothelial and steroidogenic cell migration are regulated by WNT4 in the developing mammalian gonad. Development 130 3663-3670.

Johnston H, King P \& O'Shaughnessy PJ 2007 Effects of adrenocorticotrophic hormone and expression of the melanocortin-2 receptor in the neonatal mouse testis. Reproduction 133 1181-1187.

Karl J \& Capel B 1998 Sertoli cells of the mouse testis originate from the coelomic epithelium. Developmental Biology 203 323-333.

Kero J, Poutanen M, Zhang FP, Rahman N, McNicol AM, Nilson JH, Keri RA \& Huhtaniemi IT 2000 Elevated luteinizing hormone induces expression of its receptor and promotes steroidogenesis in the adrenal cortex. Journal of Clinical Invesigation 105 633-641.

Mannan MA \& O'Shaughnessy PJ 1988 Ovarian steroid metabolism during post-natal development in the normal mouse and in the adult hypogonadal (hpg) mouse. Journal of Reproduction and Fertility $\mathbf{8 2}$ 727-734.
Mellon SH \& Miller WL 1989 Extraadrenal steroid 21-hydroxylation is not mediated by P450c21. Journal of Clinical Invesigation $\mathbf{8 4}$ 1497-1502.

Merchant-Larios H \& Moreno-Mendoza N 1998 Mesonephric stromal cells differentiate into Leydig cells in the mouse fetal testis. Experimental Cell Research 244 230-238.

Nef S \& Parada LF 1999 Cryptorchidism in mice mutant for Ins/3. Nature Genetics 22 295-299.

O'Shaughnessy PJ \& Murphy L 1993 Cytochrome P-450 17 $\alpha$-hydroxylase protein and mRNA in the testis of the testicular feminized (Tfm) mouse. Journal of Molecular Endocrinology 11 77-82.

O'Shaughnessy PJ, Marsh P \& Dudley K 1994 Follicle-stimulating hormone receptor $m R N A$ in the mouse ovary during post-natal development in the normal mouse and in the adult hypogonadal (hpg) mouse: structure of alternate transcripts. Molecular and Cellular Endocrinology 101 197-201.

O'Shaughnessy PJ, Baker PJ, Heikkila M, Vainio S \& McMahon AP 2000 Localization of $17 \beta$-hydroxysteroid dehydrogenase/17-ketosteroid reductase isoform expression in the developing mouse testis androstenedione is the major androgen secreted by fetal/neonatal leydig cells. Endocrinology 141 2631-2637.

O'Shaughnessy PJ, Fleming LM, Jackson G, Hochgeschwender U, Reed P \& Baker PJ 2003 Adrenocoricotrophic hormone directly stimulates testosterone production by the fetal and neonatal mouse testis. Endocrinology 144 3279-3284.

O'Shaughnessy PJ, Baker PJ \& Johnston H 2006 The foetal Leydig celldifferentiation, function and regulation. International Journal of Andrology 29 90-95.

Phillips DM, Lakshmi V \& Monder C 1989 Corticosteroid 11 betadehydrogenase in rat testis. Endocrinology 125 209-216.

Stalvey JR \& Payne AH 1983 Luteinizing hormone receptors and testosterone production in whole testes and purified Leydig cells from the mouse: differences among inbred strains. Endocrinology 112 1696-1701.

Val P, Jeays-Ward K \& Swain A 2006 Identification of a novel population of adrenal-like cells in the mammalian testis. Developmental Biology 299 250-256.

Vergouwen RPFA, Jacobs SGPM, Huiskamp R, Davids JAG \& de Rooij DG 1991 Proliferative activity of gonocytes, sertoli cells and interstitial cells during testicular development in mice. Journal of Reproduction and Fertility 93 233-243.

Yao HH, Whoriskey W \& Capel B 2002 Desert Hedgehog/Patched 1 signaling specifies fetal Leydig cell fate in testis organogenesis. Genes and Development 16 1433-1440.

Received 20 March 2007

First decision 20 April 2007

Revised manuscript received 27 June 2007

Accepted 18 July 2007 